\title{
Modelling the Long Run Determinants of Domestic Private Investment in Nigeria
}

\author{
Kazeem Bello Ajide ${ }^{1} \&$ Olukemi Lawanson ${ }^{1}$ \\ ${ }^{1}$ Department of Economics, University of Lagos, Lagos, Nigeria \\ Correspondence: Kazeem Bello Ajide, Department of Economics, University of Lagos, Lagos, Nigeria. E-mail: \\ kazeemajide@gmail.com
}

Received: June 19, 2012 Accepted: July 6, 2012 Online Published: October 18, 2012

doi:10.5539/ass.v8n13p139

URL: http://dx.doi.org/10.5539/ass.v8n13p139

\begin{abstract}
The paper seeks to model the long run determinants of domestic private investment in Nigeria over the period 1970 to 2010, employing advanced econometric technique of Auto-Regressive Distributed Lag (ARDL) bounds testing approach. Emanated from the estimated models are intriguing findings which showed clearly that difference exist between long and short run determinants. Public investment, real GDP, real interest rate, exchange rate, credit to the private sector, terms of trade, external debts and reforms dummy are the key long run determinants of domestic private investment while public investment, real GDP and terms of trade are statistically significant in the short run. The policy prescriptions are that necessary infrastructures to complement domestic private investment should be put in place; that external debts be reduced to the barest minimum and negative effects of external shocks engendered by foreign direct investment uncertainty and deficit terms of trade should be prevented altogether.
\end{abstract}

Keywords: domestic private investment, bound testing approach, Nigeria

\section{Introduction}

The Classicalism and Keynesianism are two major prominent political economy ideologies that have dominated economic thinking right from the emergence of earliest economists up to the time of outbreak of great depression of the twentieth century. The controversies which embroil among the adherents of each schools of thought, centered on the claim of supremacy of one over the other. The outgrowth of the ensuing controversies had successfully polarized the world economy systems into market-based, government-based or at best mixture of both. Virtually every economy world over have had its fair share of the first two but with the waves of the market-based economic system gaining more prominence, most especially among the former socialist or transitional economies. Currently, this wind of change has even blown some MENA countries.

Interestingly though is the experience of most countries within sub-Saharan Africa region with market-based ideologies, which came in the wake of IMF-led Structural Adjustment Programmes to developing countries as one of the preconditions for granting assistance upon acceptance and implementation. Notably, among these countries are those from West Africa who adopted these reform programmes during 1980s with the primary aim of applying it to correcting structural imbalances and all other forms of distortions which usually characterized pre-reforms economy. Such problems include administratively fixing of interest rates, high reserve requirements and directed credit programs to the preferred sectors, ownership as well as controlling of state-owned enterprises (SOEs) etc. All of these features, to the cynics, are capable of retarding growth processes owing largely to its inherently inefficiency, mismanagement and misallocation of resources. Hence, offers a solid basis for introducing market-led reforms by the proponents of market-based ideological philosophies.

Central to any reforms however, are role of private sectors which are seen as critical driver of economic growth arising largely from free interaction which exist between the market forces of demand and supply. Specifically, the role of domestic private investment in relation to public investment at stimulating the desired economic growth is well documented in the development economic literature. Albeit, literature is replete on the positive impact of aggregate investment on economic growth but that a large number of empirical studies have documented that private investment has a stronger, more favorable effect on growth than government investment. This was attributed to the fact that, private investment is more efficient and less closely associated with corruption. (See Seck and El Nil (1993), Oshikoya (1994), Matsheka (1998), Calamitsis et al. (1999), 
Gyimah-Brempong and Traynor (1999), Asante (2000), Ndikumana (2000), and Hoeffler (2002) for detailed narratives).

Further, the recent global financial crises which almost brought the entire world into a standstill make policy makers and other stakeholders in the economy to look inwardly at searching for alternative approaches at driving growth. Arguably, the impact of the crises was more felt by countries within Sub-Saharan region which, to a very greater extent, depend on the flows of aids, foreign direct investment, oversea development assistance and portfolio investments into the region for their development. The influx of these flows became dwindled in the wake of the financial crisis thus portending that foreign capital or other assistance as it were, may not be a sustainable source for long-term economic growth. For instance, post-financial crises report showed that about US\$ 70 billion of FDI were estimated to be cancelled in Africa in 2009 (17\% of the US\$ 393 billion of total FDI stock). African countries, with their huge development gaps, need foreign investments to boost their economies in order to lift their populations out of poverty. In view of the excruciating effects imposed by global financial crises on countries within the sub-Saharan region, it is therefore important to reposition the countries' financial stance by given consideration to effective mobilization of domestic private investment as an alternative developmental strategy for driving sustainable long term economic growth.

Nigeria, like other developing nations, adopted Structural Adjustment programs (SAP hereafter) in 1986 with the aim of correcting all the anomalies which characterized her pre-SAP era. At the core of the reforms was the framework for economic restructuring which is tangential to economic diversification away from the country's overdependence on crude oil export to other profitable non-oil sectors of the economy. Despite all the reforms that had been adopted, the country still largely relied on crude oil export revenue for her subsistence thus exposing it to any external shocks that may arise from volatility in the world oil prices. In the light of this, it is therefore argued that the potentials inherent in domestic private investments that may well serve as an alternative means of boosting the country's economic growth has not well been tapped into thus providing the motivation for undertaking this study. Available statistics however have also shown that the ratio of private investment to GDP in Nigeria is less than satisfactory. For instance, the Nigerian private sector was reported to have spent only around 21 percent of the countries national income over the period 1970-1980. Thus, private investment as a percentage of GDP dropped from 21 percent to 19 percent between 1981 and 1991 from what it was in 1970-1980 representing a drop of 47 percent. Between 1991- 2003, it further dropped by 36 percent from 11 percent to 7 percent CBN (2004). In the light of the foregoing, delving deeper into the determinants of domestic private investment behaviour in Nigeria is crucial for understanding how domestic private investment is driven in the country, as this may offer empirical guide for policy formulation.

Though, literature on investment is vast both in the developed and developing countries but studies on specific countries' experiences are scarcely available most especially for countries in the sub-Saharan Africa region. For instance, in Nigeria most studies on investment have been focused on aggregate investment but with only fewer studies credited to domestic private investment. This paper is important for a number of reasons. First, it is concerned with modelling long run relationship between domestic private investment and its determinants using an advanced econometric methodology of bound testing approach. Unlike the few earlier studies which adopted Johansen (1988) multivariate cointegration method. The use of this methodology presupposes that the underlying regressors are all integrated of order one (Pesaran et al., 2001). This is necessary because in the presence of a mixture of stationary series and series containing a unit root, standard statistical inference based on conventional likelihood ratio tests is no longer valid. For example, Harris (1995), notes that the trace and maximum eigenvalue tests from the Johansen procedure may lead to erroneous inferences when $\mathrm{I}(0)$ variables are present in the system since stationary series are likely to generate spurious cointegrating relations with other variables in the model (De Vita et al, 2005). Second, the study extends the scope of coverage period spanning from 1970 through 2010, thus validating the likely conclusion that may emanates from the findings. The import of this lies in the law of large sample size which authenticates the veracity of the study's outcome rather than basing it on erroneous conclusions drawn on small sample sizes.

The rest of the paper is organized as follows: Section 2 reviews the relevant literature on the determinants of investment, Section 3 presents the methodology and estimation techniques while Section 4 analyses the estimated private investment models. Section 5 concludes with a summary of major findings, policy implications of results and major recommendations.

\section{Literature Review}

This section offers an overview of both theoretical and empirical assessment on the determinants of investment as it relates to both developed and developing countries. This will enable the discussions to be put in context in 
what follows in the subsequent section. This particularly relates to the model specification as well as variables to be included for the eventual estimation.

Ever since Keynes who was one of the pioneers of investment theories carried out an analysis which showed the expost equality between savings and investment, the offshoots of his submission later brought about some other investment theories like accelerator theory of investment, neoclassical, Tobin's Q theory and expected profits model. Hence, these theories were theoretically identified to modelling investment in the existing investment literature.

A flexible accelerator model represents a general form of accelerator model. The basic idea of this model is that the larger the gap between the existing stock of capital and the desired capital stock, the larger would a firm's investment will be. The firm's desire is to strive as much as possible to close a fraction of the gap between the desired capital stock $\mathrm{K}^{*}$, and the actual capital stock $\mathrm{K}$, in each period. The model is expressed as: $I=\phi\left(K^{*}-K_{-1}\right)$ where $I$ stands for net investment, $K^{*}=$ desired capital stock $K_{-1}=$ last period's capital stock and $\phi=$ partial adjustment coefficient. Within the framework of the flexible accelerator model, output, internal funds, cost of external financing and other variables may be included as determinants of $\mathrm{K}^{*}$. However a particular drawback of the neoclassical model is that it does not rationalize the rate of investment or movement toward the optimal capital stock.

Another version of accelerator theory is neo-classical approach to investment which was formulated by Jorgenson (1971). In his own submission, he posited that the $K^{*}$ (desired capital stock) is proportional to output and the user cost of capital (which in turn depends on the price of capital goods, the real rate of interest, the rate of depreciation and the tax structure).

Tobin Q theory of investment is associated with Tobin (1969) is concerned with the ratio of the market value of the existing capital stock to its replacement cost (the Q ratio) is the main force driving investment. That is to say, enterprises will want to invest if the increase in the market value of an additional unit exceeds the replacement cost. Tobin argues that delivery lags and increasing marginal cost of investment are the reasons why Q would differ from unity. The main criticism of q theory is that its use tends to be chosen on an ad hoc basis rather than on optimization theory. Thus, theory is silent on the factors that govern the shape and length of the distributed lag specification. Berndt (1990) also noted that in the real practice, the model is confronted with such problems as measuring marginal rather than average user cost of capital, accounting for intangibles that affect market value and incorporating tax factors

McKinnon (1973) and Shaw (1973) also formulated neoliberal approach to investment which stresses the importance of financial deepening and high interest rates as drivers of economic growth. According to them, if economy were free up from repressive conditions, this would induce savings, investment and economic growth. In their view, investment is positively related to the real rate of interest in contrast with the neoclassical theory. This is made possible because an increase in interest rates will lead to an increase in the volume of financial savings through financial intermediaries and thereby raises investible funds, a phenomenon that McKinnon (1973) calls the "conduit effect". The same criticisms of neo-classical also apply to this model since it is a variant of the same model

Recent studies on investment have also made provision for uncertainty into investment theory due to nature of its irreversibility (see Pindyck, 1991 for details). He argued that since capital goods are often firm-specific and have a low resale value; disinvestment is more costly than positive investment. His argument was based on net present value rule which he believed must be modified to reflect an opportunity due to the irreversible nature since the firm cannot disinvest should market conditions change adversely.

More importantly, Rodrik (1991) introduces element of uncertainty as another key determinant of private investment. Apart from this, there are other theories hinging on profits or profits earned by business units and industries instead of output. This analysis of profit and investment relationship has several variants, one of which is that investment is affected by current profits, the amount of retained profits, or by other variables like output, price and sales, which reflect the profits (Chirinko (1993). The profit theory posits that the greater the gross profits, the greater will be the level of internally generated funds and in turn the greater will be the rate of investment (Zebib and Muoghalu, 1998).

In addition there is the dis-equilibrium approach, which views investment as a function of both profitability and demand for output . In this instance, investment decisions have two stages: first is the decision to expand the level of productive capacity, and second, is the decision about the capital intensity of the additional capacity (Serven and Solimano, 1992). The first decision depends on the expected degree of capacity utilisation in the economy, which provides an indicator of demand conditions, while the second decision depends on relative 
prices such as the cost of capital and labour. The investment decision takes place in a setting in which firms may be facing current and expected future sales constraints (Serven and Solimano, 1992). Therefore, investment depends both on profitability and on the prevailing sales constraints, which determine the rate of capacity utilisation (Serven and Solimano, 1992). Criticism of the models arises because the models are not clear on the role of cash flow.

It is discernable from brief theoretical expositions that private investment variables can be drawn from different schools of thought namely: Keynesian, neoclassical, neoliberal and uncertainty since each of them have their inherent drawbacks.

We provide a brief overview of empirical studies on private investment from both developed and developing countries' experiences and this is presented below.

Dailami and Walton (1992) examined the behavior of private investment in Zimbabwe over the period 1970 to 1987. The results showed that private investment is positively related to GNP growth, real interest rate, real effective exchange rate, and the lagged dependent variable, and negatively related to the government bond yield, relative price of capital goods, and real wage.

Asante (2000), analyzed the determinants of private investment in Ghana using a time series analysis and complementing it with a cross-sectional one over the period 1970-1992. The results showed that the variables that had a significant positive relationship with investment are: lagged investment, public investment, private sector credit, real interest rate, and real exchange rate. Trade, political instability, macroeconomic instability, and the growth rate of real GDP have had a negative relationship with private investment. Ribeiro (2001) employed the Johansen multivariate co-integration technique and Engle-Granger Two Step approach to model private-sector investment in Brazil during the period 1956-1996. The results reveal a positive impact of the output, public investment and financial variables and the negative effect of exchange rate. He also conducted weak exogeneity and superexogeneity tests and the results confirmed the importance of credit and public investment as economic policy instruments. Luintel and Mavrotas (2005), investigated domestic private investment behaviour in a panel of 24 low-income and middle-income countries spanning a period of 1981-2000. The paper rigorously addresses (i) the cross-country heterogeneity in private investment behaviour, and (ii) endogeneity. Indicators of financial sector development and other standard macroeconomic determinants of private investment appear significant in explaining private investment behaviour in our sample; however, the estimated parameters and adjustment dynamics exhibit important cross-country differences. Lesotlho (2006), An Investigation of the determinants of private Investment: The Case of Botswana. The econometric results of the study support the existence of a short-run dynamic adjustment and the long run equilibrium relationship between these macroeconomic variables and private investment level. Public investment, bank credit to the private sector and the real interest rate affect private investment level in the short run, while GDP growth and real exchange rate affect private investment in the long run.

More recently, Frimpong and Marbuah (2010), sought an empirical assessment of factors that have either stimulated or dampened private sector investment in Ghana. Employing co-integration and error correction techniques within an ARDL framework their results suggest that private investment is determined in the short-run by public investment, inflation, real interest rate, openness, real exchange rate and a regime of constitutional rule, while real output, inflation, external debt, real interest rate, openness and real exchange rate significantly influenced private investment response in the long-run. Fowowe (2011), conducted an empirical investigation of the effect of financial sector reforms on private investment in selected Sub-Saharan African countries. An index is developed to track the gradual progress made with implementation of the phases of the reforms. The results of econometric estimations show that financial sector reforms (measured by the index) have had a positive effect on private investment in the selected countries considered for his study, thus offering support to the financial liberalization hypothesis.

It is instructive to note that even though determinants of private domestic investment have attracted some attention in the literature, it has not been studied extensively. Among the few that have considered individual countries are Busari and Omoke (2010), Akanbi (2010).

Busari and Omoke (2008), presented an empirical assessment of the impact of trade policy practice and its credibility on private investment using firm level data of 67 Nigerian firms over the period 1980-2003. The results underscore the robustness of the links among private investment, trade policy and macroeconomic uncertainty. Many of the trade and volatility measures considered show strong negative association with private investment. Furthermore, the study observed that trade policy practice in Nigeria has deterred investment by making the cost of importing high, which particularly affects firms with high import intensity. In addition, the 
negative impact of real exchange rate uncertainty on investment is significantly larger in firms that are import intensive. Akanbi (2010), empirically examined the pattern of domestic investment in Nigeria using a neoclassical supply-side model over the period 1970 to 2006. To achieve this objective, he therefore employs the Johansen estimation techniques. The results show that real output, user cost of capital, and the level of financial development and the governance indicators are significant determinants of domestic investment in Nigeria.

\section{Methodology}

This section of the paper discusses the analytical framework that underpins the empirical analysis of the determinants of private domestic investment in Nigeria. Relevant data issues are also discussed, drawing on earlier studies.

\subsection{Analytical Framework}

Unlike some previous studies which have been anchoring the framework of their studies on any one of the investment theories earlier reviewed. As earlier pointed out, each of these models is confronted with certain inherent drawbacks. Hence, our study follows that of Asante (2000) by adopting an eclectic model in which we specify the determinants of private investment as consisting of Keynesian, neoclassical, neo-liberal and uncertainty variables. The long run private domestic investment function is therefore expressed empirically as:

$$
\begin{gathered}
L N P R I N V=f(P U I N V \cdot L N R G D P, I N F, E X R \cdot R I N R, L N C R P R V, L N T O T, L N E X D E B, \\
\text { LNFDI,DUREM })
\end{gathered}
$$

Where

$L N P R I N V=\log$ of private domestic investment

$L N P U I N V=$ Log of public investment

$L N R G D P=\log$ of real gross domestic product

$I N F=$ Rate of Inflation

$E X R=$ Real exchange rate (nominal exchange rate deflated by Consumer Price Index(CPI))

$R I N R=$ Real rate of interest rate (proxied by real lending rate)

$L N C R P R V=\log$ of real credit to the private sector

$L N T O T=$ Log of export divided by import price multiplied by 100

$L N E X D E B=\log$ of external debt

$L N F D I=\log$ of foreign direct investment

DUREM = Dummy for reforms undertaken by the country: $\mathrm{D}=1$ from 1986 till 2010, and zero otherwise.

$\varepsilon=$ uncorrelated error term

The explicit estimable econometric model is formulated as follows:

$$
\begin{gathered}
L N P R I N V=\psi_{0}+\psi_{1} L N P U I N V+\psi_{2} L N R G D P+\psi_{3} I N F+\psi_{4} E X R+\psi_{5} R I N R+ \\
\psi_{6} L N C R P R V+\psi_{7} L N T O T+\psi_{8} L N E X D E B+\psi_{9} L N F D I+ \\
\psi_{10} D U R E M+\varepsilon_{t} \\
\psi_{2}, \psi_{6}, \psi_{9}, \psi_{10}>0 \quad \psi_{3}, \psi_{8},<0 \text { while } \psi_{1}, \psi_{4}, \psi_{5}, \psi_{7} \text {, can be }>\text { or }<0 \text { that is ambiguous }
\end{gathered}
$$

Some variables were $\log$ transformed so that the problem of heteroskedasticity can be reduced since it compresses the scale in which the variables are measured, thereby reducing a tenfold difference between two values to a twofold difference (Gujarati,1995). While some variables were not log transformed because they are already in their rates examples include inflation, real interest rate and real exchange rate.

Economic theory suggests an increase in real GDP is expected to result in a greater amount of real private domestic investment to be undertaken, thus a positive relationship is hypothesized. The relationship between public and private domestic investment is ambiguous because public investment may either crowding out or in domestic private investment. The former may occur through what is referred to as Ricardian Equivalence Theorem (RET). This situation may occur through increased deficits and a high interest rate. Empirical studies by Chiber and Wijnbergen (1988) and Rossiter (2002) report a negative effect of public investment on private investment. The latter is also possible via boosting of private investment by increasing private returns through the provision of infrastructures (Communication, transports, energy, etc). Evidence of a complementarity between public and private saving has been found by studies such as Blejar and Khan (1984), Aschauer (1989), 
and Greene and Villanueva (1991). Positive relationship is hypothesized between credit to the private sector and private investment. Private firms in developing countries rely heavily on bank credit as a source of financing.

The inflation which acts as a surrogate for macroeconomic instability is expected to bear a negative relationship with private domestic investment. High and volatile inflationary trends tend to increase uncertainty level thus adversely affect private investment. Also, the effect of real exchange rate is ambiguous from the theoretical point of view. The effects vary from real exchange depreciation or appreciation as the case may be. The effect of real interest rate which measures the user cost of capital is ambiguous. Under the neoclassical investment model, real interest rate is treated as a key component of the user cost of capital and therefore affects private investment negatively. However, there is also the argument that a higher real interest rate increases the flow of bank credits, which complements the private sector savings and facilitates private capital formation and hence private investment. A high interest rate may discourage investors from lending from banks thereby having diminutive effects on the quantum of investment that ought to have been undertaken. Certain studies (Green and Villanueva 1991, Solimano 1992) have confirmed the negative relationship between interest rates and investment; studies by others (Serven and Solimano 1993, van Wijnbergen 1985a, 1985b) have shown that in repressed financial markets, credit policy affects investment in a distorted manner.

A term of trade variable which is a proxy for external shocks is expected to have either negative or positive relationship with private domestic investment. For instance, if a negative term of trade is recorded, this may worsen the current account deficit and exert a negative effect on private investment. Conversely, a positive relationship may be expected if term of trade turns positive. Hence, the relationship between term of trade and private domestic investment is ambiguous.

According to Asante (2000) external debt burden are expected theoretically to hamper private investment through at least three channels First, debt service requires an external transfer that, under conditions of limited external financing, leads to reduced investible resources. Second, the anticipated "tax" associated with future debt service (the debt overhang) reduces the anticipated return on investment. Third, uncertainty about the policies needed in the future to meet an equally uncertain debt service also tends to depress investment (Serven and Solimano, 1992 or 1993? 4). Lastly, the foreign direct investment is expected to influence the development of private domestic investment positively. Hence, a positive relationship is hypothesized.

\subsection{Estimation Technique}

The study adopts an Auto-Regressive Distributed Lag (ARDL) bounds testing approach developed by Pesaran et al (2001) to modelling the long run determinants of domestic private investment. This approach has some econometric advantages over the Engle-Granger (1987) and maximum likelihood based approach proposed by Johansen and Juselius (1990) and Johansen (1991) cointegration techniques. Firstly, the bounds test does not require pre-testing of the series to determine their order of integration since the test can be conducted regardless of whether they are purely I(1), purely $\mathrm{I}(0)$, or fractionally integrated. Second, endogeneity problems and inability to test hypotheses on the estimated coefficients in the long-run associated with the Engle-Granger (1987) method are avoided. According to Pesaran and Shin (1999), modeling the ARDL with the appropriate lags will correct for both serial correlation and endogeneity problems. Jalil et al (2008) argue that endogeneity is less of a problem if the estimated ARDL model is free of serial correlation. In this approach, all the variables are assumed to be endogenous and the long run and short run parameters of the model are estimated simultaneously (Khan el al, 2005).Third, as argued in Narayan (2005), the small sample properties of the bounds testing approach are far superior to that of multivariate cointegration (Halicioglu, 2007). The approach, therefore, modifies the Auto-Regressive Distributed Lag (ARDL) framework while overcoming the inadequacies associated with the presence of a mixture of $\mathrm{I}(0)$ and $\mathrm{I}(1)$ regressors in a Johansen-type framework. Four, Secondly, the long and short-run parameters of the model in question are estimated simultaneously. Lastly, The ARDL has superior small sample properties as compared to the Johansen and Juselius (1990) cointegration test (Pesaran and Shin, 1998).

An ARDL representation of equation (1) can be specified as follows:

$$
\begin{gathered}
\Delta L N P R I N V=\varpi_{0}+\sum_{i=1}^{q} \omega_{1} \Delta L N P R I N V_{t-i}+\sum_{i=1}^{q} \omega_{2} \Delta L N P U I N V_{t-i}+\sum_{i=1}^{q} \omega_{3} \Delta L N R G D P_{t-i}+\sum_{i=1}^{q} \omega_{4} \Delta I N F_{t-i}+\sum_{i=1}^{q} \omega_{5} \Delta E X R_{t-i}+ \\
\sum_{i=1}^{q} \omega_{6} \Delta R I N R_{t-i}+\sum_{i=1}^{q} \omega_{7} \Delta L N C R P R V_{t-i}+\sum_{i=1}^{q} \omega_{8} \Delta L N T O T_{t-i}+\sum_{i=1}^{q} \omega_{9} \Delta L N E X D E B_{t-i}+
\end{gathered}
$$




$$
\begin{aligned}
& \sum_{i=1}^{q} \omega_{10} \Delta L N F D I_{t-i}+\lambda_{1} L N P R I N V_{t-1}+\lambda_{2} L_{N P U I N V_{t-1}}+\lambda_{3} L N R G D P_{t-1}+\lambda_{4} I N F_{t-1}+ \\
& \lambda_{5} E_{t-1}+\lambda_{6} R_{I N R_{t-1}}+\lambda_{7} L_{N C R P R V_{t-1}}+\lambda_{8} L_{N T O T_{t-1}}+\lambda_{9} L N E X D E B_{t-1}+ \\
& \lambda_{10} L N F D I+\mu_{t}
\end{aligned}
$$

Where $\Delta$ is the first difference of a variable

$L N$ indicates that the data set are expressed in natural logarithms,

$\varpi_{0}$ is a constant

$q$ is a maximum lag order,

$\omega_{1}, \ldots \ldots \ldots \ldots \ldots \omega_{10}$ represent the short-run coefficients (error correction dynamic),

$\lambda_{1}, \ldots \ldots \ldots \ldots \ldots . . . . . \lambda_{10}$ correspond to the long-run relationship,

$i$ time trend, and,

$\mu_{t}$ is the white noise error.

The implementation of the ARDL approach involves two stages. First, the existence of the long-run nexus (cointegration) between variables under investigation is tested by computing the F-statistics for analyzing the significance of the lagged levels of the variables. (Pesaran, Shin, and Smith, 1999) and (Narayan, 2004) have provided two sets of appropriate critical values for different numbers of regressors (variables). This model contains an intercept or trend or both. One set assumes that all the variables in the ARDL model are of I(0), and another assumes that all the variables are I(1). If the F-statistic lies above the upper-bound critical value for a given significance level, the conclusion is that there is a non-spurious long-run level relationship with the dependent variable. If the F-statistic lies below the lower bound critical value, the conclusion is that there is no long-run level relationship with the dependent variable. If it lies between the lower and the upper limits, the result is inconclusive. The general form of the null and alternative hypotheses for the F-statistic test is as follows:

$$
\begin{gathered}
H_{0}: \lambda_{P R I N V}=\lambda_{\text {PUINV }}=\lambda_{R G D P}=\lambda_{I N F}=\lambda_{\text {EXR }}=\lambda_{\text {RINR }}=\lambda_{\text {CRPRV }}=\lambda_{\text {TOT }}=\lambda_{\text {EXDEB }}=\lambda_{I F D I}=0 \\
H_{1}: \lambda_{\text {PRINV }} \neq \lambda_{\text {PUINV }} \neq \lambda_{\text {RGDP }} \neq \lambda_{I N F} \neq \lambda_{\text {EXR }} \neq \lambda_{\text {RINR }} \neq \lambda_{\text {CRPRV }} \neq \lambda_{\text {TOT }} \neq \lambda_{\text {EXDEB }} \neq \lambda_{\text {FFI }} \neq 0
\end{gathered}
$$

Secondly, if the cointegration between variables is identified, then one can undertake further analysis of long-run and short-run (error correction) relationship between the variables.

The error correction representation of the series can be specified as follows:

$$
\begin{gathered}
\Delta L N P R I N V=\varpi_{0}+\sum_{i=1}^{q} \omega_{1} \Delta L N P R I N V_{t-i}+\sum_{i=1}^{q} \omega_{2} \Delta L N P U I N V_{t-i}+\sum_{i=1}^{q} \omega_{3} \Delta L N R G D P_{t-i}+\sum_{i=1}^{q} \omega_{4} \Delta I N F_{t-i}+\sum_{i=1}^{q} \omega_{5} \Delta E X R_{t-i}+ \\
\sum_{i=1}^{q} \omega_{6} \Delta R I N R_{t-i}+\sum_{i=1}^{q} \omega_{7} \Delta L N C R P R V_{t-i}+\sum_{i=1}^{q} \omega_{8} \Delta L N T O T_{t-i}+\sum_{i=1}^{q} \omega_{9} \Delta L N E X D E B_{t-i}+ \\
\sum_{i=1}^{q} \omega_{10} \Delta L N F D I_{t-i}+\xi E C M_{t-1}+v_{1} D U R E M+\mu_{t}
\end{gathered}
$$

Where $\xi$ the speed of adjustment process and ECM is is the residuals obtained from equation (1) while other variables remain as earlier defined. The coefficient of the lagged error term correction term is expected to be negative and statistically significant to further support the existence of a cointegrating relationship.

\subsection{Data Source}

The study employs secondary sources of data spanning 1970 through 2010 where nine determinants of private domestic investment are used to estimate the private investment models. The choice of the study period is limited by the data availability consideration on most of the variables used in the study. The data is drawn from the World Bank's World Development Indicators, 2010 (CD-ROM) and African Development Indicators (various issues), IMF's International Financial Statistics CDROM (various issues), Central Bank of Nigeria Statistical Bulletin,2010 and Central Bank Annual Reports(various issues).

\section{Empirical Results and Discussion}

As a prelude to any estimation of models, the time series properties of the variable of interest

need to be tested. This is presented in table 1. Both the Augmented Dickey-Fuller (ADF) and Phillips perron unit root tests were conducted. The results of both tests were not significantly different from each other. The results 
show that the ADF statistics and Phillip perron for all the variables exceeded their critical values at least at the $5 \%$ significant level. The implication is that all the variables are found to be non-stationary, that is they are characterized as $\mathrm{I}(0)$ series.

However, once first differences of the variables are considered the null hypothesis of unit root can be rejected, as the t-statistics are lower than 5 percent critical values. This is an indication that the variables are I(1).

Table 1. ADF and PP unit root tests for stationarity

\begin{tabular}{|c|c|c|c|c|c|c|c|}
\hline & \multicolumn{3}{|c|}{ Augmented Dicken Fuller (ADF) } & \multicolumn{4}{|c|}{ Phillip Perron (PP) } \\
\hline Variable & $\begin{array}{l}\text { Intercept Without } \\
\text { Trend }\end{array}$ & $\begin{array}{l}\text { Intercept } \\
\text { Trend }\end{array}$ & With & $\begin{array}{l}\text { Intercept V } \\
\text { Trend }\end{array}$ & Without & $\begin{array}{l}\text { Intercept } \\
\text { Trend }\end{array}$ & With \\
\hline LNPRINV & -1.7657 & $-3.6750 * *$ & & $-3.1319 *$ & & $-3.7044 * * *$ & \\
\hline$\triangle$ LNPRINV & $-10.5928 * * *$ & $-10.5034^{* * *}$ & & $-10.9769 * * *$ & & $-10.9286^{* * *}$ & \\
\hline LNPUINV & -1.0883 & -2.4369 & & -1.0892 & & -2.5552 & \\
\hline$\triangle$ LNPUINV & $-6.8513 * * *$ & $-6.8952 * * *$ & & $-6.8384 * * *$ & & $-6.8741 * * *$ & \\
\hline LNRGDP & -2.3295 & -2.0661 & & $-5.4371 * * *$ & & -1.8966 & \\
\hline$\Delta$ LNRGDP & $-5.8298 * * *$ & $-6.1308^{* * *}$ & & $-5.8455^{* * *}$ & & $-6.9165 * * *$ & \\
\hline INF & $-3.2066^{*}$ & $-3.1608^{*}$ & & $-3.1094 *$ & & $-3.0546^{*}$ & \\
\hline$\Delta \mathrm{INF}$ & $-6.1603 * * *$ & $-6.1172 * * *$ & & $-10.4774 * * *$ & & $-11.6086^{* * *}$ & \\
\hline EXR & 0.2353 & -1.6073 & & 0.0972 & & -1.6793 & \\
\hline$\Delta \mathrm{EXR}$ & $-5.4335 * * *$ & $-5.5482 * * *$ & & $-5.4468 * * *$ & & $-5.5471 * * *$ & \\
\hline RINR & -1.4749 & -1.5703 & & -1.9278 & & -2.8063 & \\
\hline$\Delta \mathrm{RINR}$ & $-9.9239 * * *$ & $-9.8500 * * *$ & & $-9.9719 * * *$ & & $-10.0025^{* * *}$ & \\
\hline LNCRPRV & 0.3143 & -1.6509 & & 0.3188 & & -1.9857 & \\
\hline$\triangle \mathrm{LNCRPRV}$ & $-4.7352 * * *$ & $-4.7307 * * *$ & & $-4.5517 * * *$ & & $-4.5515 * * *$ & \\
\hline LNTOT & -0.6117 & -1.6695 & & -0.6467 & & -1.7141 & \\
\hline$\Delta \mathrm{LNTOT}$ & $-6.0909 * * *$ & $-6.0627 * * *$ & & $-6.0938 * * *$ & & $-6.0646 * * *$ & \\
\hline LNEXDEB & -1.5109 & -0.3846 & & -1.5132 & & -0.3804 & \\
\hline$\triangle$ LNEXDEB & $-5.8975^{* * *}$ & $-6.2501 * * *$ & & $-5.8975^{* * *}$ & & $-6.2672 * * *$ & \\
\hline LNFDI & -1.2175 & -1.2388 & & -1.8991 & & $-5.2267 * * *$ & \\
\hline$\triangle \mathrm{LNFDI}$ & $-8.1321 * * *$ & $-8.1353 * * *$ & & $-15.4388 * * *$ & & $-13.7494 * * *$ & \\
\hline
\end{tabular}

Notes: The null hypothesis is that the series is non-stationary, or contains a unit root. ${ }^{* *},{ }^{* *},{ }^{*}$ denotes the rejection of null hypothesis of unit root at the $1 \%, 5 \%$ and $10 \%$ significance levels respectively. Test statistics for both ADF and PP are compared with simulated critical values from MacKinnon 1996, Table 1). The lag length in the ADF test is based on the Akaike Information Criterion (AIC), while for the PP test bandwidth selection is based on Newey West. $\Delta$ is first difference operator.

\subsection{Bound Tests for Cointegration}

Results of the bounds test procedure for co-integration analysis between real domestic private investment and its determinants are presented in table 2. The cointegration test under the ARDL bounds framework involves the comparison of the F-statistics against the critical values.

Table 2. Bounds test for cointegration analysis

\begin{tabular}{lll}
\hline Critical value & Lower Bound Value & Upper Bound Value \\
\hline $1 \%$ & 3.74 & 5.06 \\
$5 \%$ & 2.86 & 4.01 \\
$10 \%$ & 2.45 & 3.52
\end{tabular}

Calculated F-Statistics $=5.647$

$F_{\text {PRINV }}(P R I N V \mid P U I N V, R G D P, I N F, E X R, R I N R, C R P R V, T O T, E X D E B, F D I, D U R E M)$

Note: Computed F-statistic: 5.508 (Significant at 0.05 marginal values).Critical Values are cited from Pesaran et al. (2001), Table CI (iii), Case 111: Unrestricted intercept and no trend. 
The results show that the computed $F$-statistic of $=5.647$ is greater than the lower critical bound value of 3.74 . Thus, the null hypotheses of no cointegration are rejected, implying long-run co integration relationships among the variables.. Hence, there is a long-run relationship between domestic private investment and its determinants.

\subsection{Results of the Long Run ARDL Model of Private Investment in Nigeria}

Having established that real domestic private investment and its determinants are cointegrated, the long-run parameters of the ARDL model are estimated and the results are presented in the table below. The long-run ARDL model was estimated based on the Akaike Information Criterion (AIC) using a lag of one given the annual nature and relatively short sample properties of the data.

From table 3 it can be seen that seven out of ten variables of interest are statistically significant in the long run except for inflation, term of trade and foreign direct investment. Also, virtually all the coefficients of the estimated model carry their hypothesized signs except for inflation with a positive sign.

Table 3. Long run estimates of ARDL model

\begin{tabular}{cccc}
\hline $\begin{array}{c}\text { ARDL (1,1,1,1,1,0,0,1,1) selected based on Akaike Information } \\
\text { Criteria(AIC) }\end{array}$ & \multicolumn{2}{c}{ Dependent Variable: LNPRINV } \\
\hline Regressor & Coefficient & $\begin{array}{c}\text { Standard } \\
\text { Error }\end{array}$ & T-Ratio \\
& -15.8225 & 12.3307 & $-3.2832^{* * *}$ \\
Constant & -3.4752 & 1.2579 & $-2.7626^{* *}$ \\
LNPUINV & 3.1603 & 1.9069 & $2.5573^{* *}$ \\
LNRGDP & 0.0255 & 0.0345 & 0.7390 \\
INF & 0.0519 & 0.0263 & $1.9755^{*}$ \\
EXR & 0.4250 & 0.1770 & $2.4014^{* *}$ \\
RINR & 3.4201 & 1.2913 & $2.6486^{* *}$ \\
LNCRPRV & 0.7552 & 1.2112 & 0.6235 \\
LNTOT & -3.2162 & 1.0039 & $-3.2037^{* * *}$ \\
LNEXDEB & 1.0876 & 0.9711 & 1.1199 \\
LNFDI & 3.1939 & 3.0208 & $3.2642^{* * *}$ \\
DUREM & &
\end{tabular}

Note: $* * *(* *) *$ denotes significance at $1 \%(5 \%) 10 \%$ levels respectively

The coefficient on public investment variable is statistically significant at $5 \%$ level thus suggesting that if public investment were to increase by $1 \%$, real private domestic investment will decline by $3.47 \%$. This result clearly explains the Nigerian situation where most of the infrastructures like electricity, transportation, water supply and roads are in deplorable conditions. Infact they have totally collapsed, this is suggestive of crowding out of private domestic investment by public investment. For instance, in Nigeria most businesses have closed down and opted out for other countries due to erratic and epileptic power supply and deplorable motorways, all these have consequently led to increasing cost of production. This findings thus contradicting some earlier studies ( like Blejar and Khan (1984), Aschauer (1989), and Greene and Villanueva (1991)) that have documented complementarity effect between private and public investment. Real GDP is correctly signed and significant at $5 \%$ level. If Real GDP were to increase by $1 \%$, private domestic investment will increase by $3.16 \%$ thus lending credence to accelerator principle effect. The findings confirm to some previous studies like Ibrahim (2000), Asante (2000), Akpalu (2002), Outtarra (2005), Frimpong and Marbuah (2010) among other studies. The positive sign of inflation is a repudiation of economic postulate that requires private domestic investment to thrive well in a low and stable inflation environment. The corollary of this finding is that as prices of goods and services are soaring higher in Nigeria, a profit maximize individual sees it as an opportunity to make abnormal profits, thus venturing into such businesses in order to partake in the perceived excessive gains. This result is consistent with studies like Acosta (2005) for Argentina and Frimpong and Marbuah (2010) for Ghana. The coefficient on exchange rate is also positive and statistically significant at $10 \%$ level. The introduction of SAP in the $80 \mathrm{~s}$ has led to persistent depreciation of naira and may have led to increased domestic private investment. This is possible as cost of domestic and exported goods became relatively cheaper as compared to the rising cost of imported goods counterpart. Also, the real interest rate effect is found to be positive. Albelt, our finding contradicts neo-classical theory of the user cost of capital but however, lending support to the complementarity 
hypothesis of McKinnon and Shaw (1973). The repressed nature of real interest rate of pre-SAP era might have accounted for discouragement of fund suppliers from saving with banks. The higher interest rates of financial liberalization period largely induced more domestic savings which later translating into more private investment being undertaken through increased investible fund.

Further, the coefficient on credit to private sector has the right sign and statistically significant at $5 \%$ level. Thus implying that as more credits are extended to the private sectors, the more domestic private investments were being undertaken. This is strongly confirmed by studies like Asante,(2000); and Frimpong and Marbuah (2010). An increase of private credit to private sector by $1 \%$, will result in an increase of $3.24 \%$. Our results contradicts that of Oshikoya (1994) who found that increases in credit to the private sector were not associated with increases in private investment for Morocco, Tanzania, and Zimbabwe. The stock of external debts is another important variable which influences the growth of domestic private investment in Nigeria. It has the expected negative sign as well as being statistically significant at a very conventional level of $1 \%$. This goes to show that external debt constitutes a drag on growth and development of domestic private investment in most developing nations where debt overhang as well as accompaniment of accumulated debt interests have assumed alarming and unmanageable proportions. As for the Nigerian case, an increase of $1 \%$ in the stock of debts reduces private domestic investment by $3.22 \%$.

The coefficients of the estimated variables like term of trade and foreign direct investment albeit carry the expected signs but statistically insignificant at any conventional levels. For instance, term of trade variable has a positive sign but not significant at any benchmarking decision criteria. Similar intuitive argument also holds for foreign direct investment variable but with a different conclusion being drawn on empirical ground. This assertion may seem plausible enough since several studies have found evidence to support the fact that most FDI inflows are mostly targeted and benefitted by extractive industries (see Africa Economic Research Consortium (2004) and Adam (2009) for detail narratives). The reform periods in Nigeria ushered in its wake the development of most businesses in the private sectors as privatization and commercialization exercises took off. This explains why the dummy capturing reforms is highly significant at a $1 \%$ level.

Table 4 presents the results of error correction of the ARDL approach and the short-run relationship of the variables as well. Emanating from the short run dynamic models are intriguing findings and these are noticeable in three major ways. First, some variables which are formerly carrying positive hypothesized signs in the long run model has turned negative in the short run. Examples include exchange rates and foreign direct investment. Two, some variables which were statistically significant in the long run are not significant in the short run; this is suggestive of occurrence of time lagged effects. Third, seven (excluding intercept) of the explanatory variables are statistically significant in the long run while just three (excluding intercept) are significant in the short run models.

Table 4. Results of the short run dynamic model

\begin{tabular}{cccc}
\hline $\begin{array}{l}\text { ARDL (1,1,1,1,1,0,0,1,1) selected based on Akaike } \\
\text { Information Criteria(AIC) }\end{array}$ & \multicolumn{2}{c}{ Dependent Variable: } & $\Delta$ (LNPRINV) \\
\hline Regressor & Coefficient & Standard Error & T-Ratio \\
Constant & -6.7989 & 8.9414 & $-4.1050^{* * *}$ \\
$\Delta$ (LNPUINV) & -4.1824 & 1.0249 & $-4.0807^{* * *}$ \\
$\Delta$ (LNRGDP) & 4.8897 & 1.6823 & $2.9066^{* *}$ \\
$\Delta$ (INF) & 0.0167 & 0.0294 & 0.5697 \\
$\Delta$ (EXR) & -0.0800 & 0.0487 & -1.6431 \\
$\Delta$ (RINR) & 0.1953 & 0.1161 & 1.6822 \\
$\Delta$ (LNCRPRV) & 3.5948 & 2.8792 & 1.2485 \\
$\Delta($ LNTOT) & 3.1968 & 1.2514 & $2.5545^{* *}$ \\
$\Delta$ (LNEXDEB) & -1.5903 & 1.2322 & -1.2906 \\
$\Delta($ LNFDI $)$ & -0.1350 & 0.5805 & -0.2326 \\
$\Delta$ (DUREM) & 1.7861 & 2.6893 & 0.6641 \\
ECM(-1) & -0.6732 & 0.2166 & $-5.8778^{* * *}$
\end{tabular}


$E C M=L N P R I N V+6.1432^{*}$ LNPUINV $-0.0923^{*} L N R G D P-2.0123^{*} I N F+1.9812^{*}$ EXR $-1.4325^{*}$ RINR $1.1564^{*} L N C R P R V-3.1908^{*} L N T O T+2.2109^{*} L N E X D E B+0.0167^{*} L N F D I+4.8709^{*} C$

Model Criteria

$\begin{array}{cccc}\mathrm{R}^{2} & 0.7215 & \mathrm{R}^{2} \text {-Adjusted } & 0.6120 \\ \text { S.E of Regression } & 2.3259 & \text { F-Stat } & 6.5930 \\ \text { AIC } & .4 .7694 & \text { SBC } & -5.2760 \\ \text { DW } & 1.8183 & \text { RSS } & 1.3259\end{array}$

Note: $* * *(* *) *$ denotes significance at $1 \%(5 \%) 10 \%$ levels respectively.

The public investment still retains its negative hypothesized sign just like the long run results and statistically significant at the 1 percent level. In fact countless studies in Nigeria have documented the crowding out effects of Nigeria's government investment on businesses. Therefore, it is not surprising that similar results also emanated in the short run dynamic models. Thus, if government investment were to increase by 1 percent, real domestic private investment will reduce by 4.18 percent. Interestingly, the magnitude of changes is greater in the short run than in the long run. This seems reasonable as surviving businesses would have gotten adapted to the situation while the potential entrants would have factored it in their cost estimates. For instance, amid the turbulent and harsh investment climate in Nigeria, some banks are still operating and run on private generators for more than 15 hours daily while at the same time some new businesses are still springing up by the day. What this implies in effect is that non-availability of these basic facilities are no longer an excuse in doing businesses in Nigeria but rather a stark reality that have to be factored in the cost function. This result contradicts that of Frimpong and Marbuah (2010) for Ghana whose findings revealed crowding-in effect of public private investment in the short run at $5 \%$ level of significance. Also, Looney and Frederiken (1997) found that in Pakistan, public investment crowds out private investment in non-manufacturing and small-scale manufacturing activities.

The impact of real GDP on domestic private investment is positive and significant at the $5 \%$ level which similar to that of long run model. The accelerated principle effects is further reinforced as $1 \%$ increase in the real GDP will induce about $5 \%$ increase in domestic private investment. Quite a large number of studies unequivocally lend support to this outcome.

The coefficient on Inflation is positive but statistically insignificant at any conventional levels just like what was obtained in the long run model. What this suggests is that inflation is a spur rather a drag on domestic private investment as far as Nigeria is concerned. This result is consistent with studies like Acosta (2005) for Argentina and Frimpong and Marbuah (2010) for Ghana. Another intriguing result emanates when the exchange rate is negative as well as insignificant in the short run unlike in the long run when it was positive and statistically significant. The implication of this is that in the short run depreciation of naira or devaluation could not stimulate increased domestic private investment until in the long run when the time lagged effects started paying off. In addition, the real rate of interest still retains its positive sign but not statistically significant at any conventional levels. The situation of short run insignificance to the long run significance can be better explained with time lagged effects. Another plausible reason may be likened to the peoples' preference for holding of stocks to savings which they perceived as effective inflation-hedgers in relation to banking which they believed erode the value of their money as inflation rises.

Credit to the private sector though has the expected positive sign but not statistically significant in the short run. One explanation for this may be linked to the amount of credit extended to the private economic units may not actually be enough to induce any significant changes on domestic private investment because the loan demanders may not possess the requisite collateral assets to obtain the required loans sourced for at least in the short run. For instance in Nigeria hardly has any private sector obtains $100 \%$ loans sourced for without being slashed, this explains why businesses cannot expand as they wish.

The coefficient of term of trade bears the expected sign as well as statistically significant at the $5 \%$ level. That is, $1 \%$ increase in the terms of trade will induce $3.196 \%$ increase in domestic private investment as indicated in the table above. What this implies is that in the short run a favourable terms of trade is capable of stimulating increased domestic private investment. In addition, while external debts have the hypothesized negative sign and the coefficient on foreign direct investment does not conform to expected sign thus contradicting theoretical economic postulate which requires a positive relationship between FDI and domestic private investment. Though, the impacts of external debts and FDI variables are not statistically significant in the short run. The dummy for 
reforms is not statistically different from zero as shown by $\mathrm{t}$-value of 0.6641 whereas its impact was more conspicuous in the long run. In addition, the coefficient of the lagged error correction term (-0.6732) is negative and statistically significant at the 1 percent level. The negative and significant coefficient is an indication of cointegrating relationship between domestic private investment and its determinants. The magnitude of the coefficient implies that 67 percent of the disequilibrium caused by previous year's shocks converges back to the long-run equilibrium in the current year.

Finally, the structural stability of the long-run and short-run relationships for the entire period is examined by the cumulative sum (CUSUM) and the cumulative sum of squares (CUSUMSQ) of the recursive residual test which proposed by (Brown et al, 1975). The null hypothesis of these tests is that the regression equation is correctly specified. These two tests are presented in figure 1 and 2 . The pair of straight lines is each figure indicates the 5 per cent significant level and if the plotted CUSUM and SUSUMSQ graphs remain inside the straight lines the null hypothesis of correct specification of the model can be accepted. Otherwise, the null hypothesis is rejected and it can be concluded that the regression equation is miss-specified. The two figures reveal that the plots of CUSUM and SUSUMSQ stay within the lines, and, therefore, this confirm the equation 1 is correctly specified and stable. The selected models adopted in the study seem to be good and robust in estimating the short and long-run relationships between domestic private investment and the determinants considered.

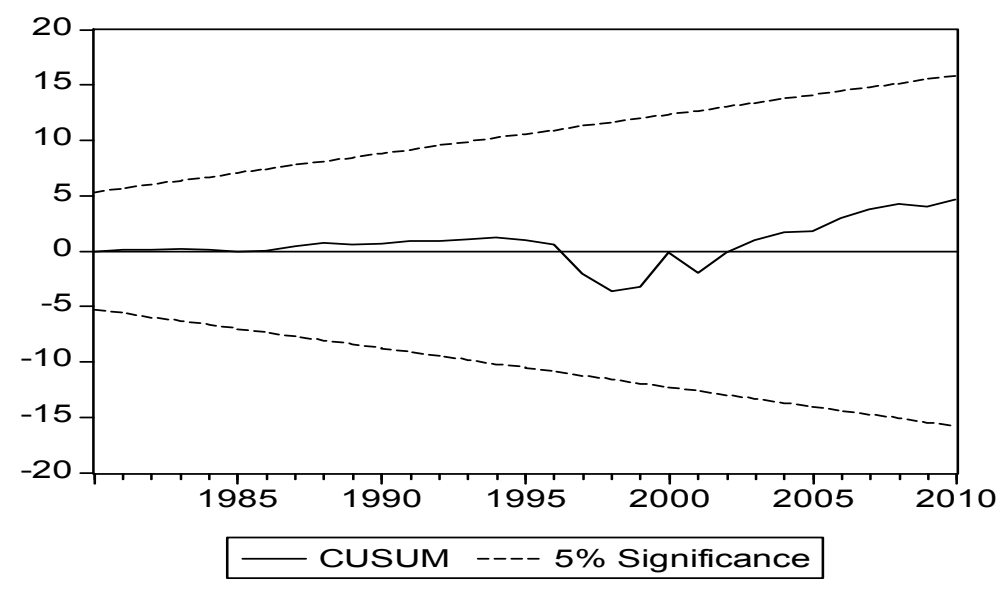

Figure 1. Plotting of CUSUM statistics for stability test

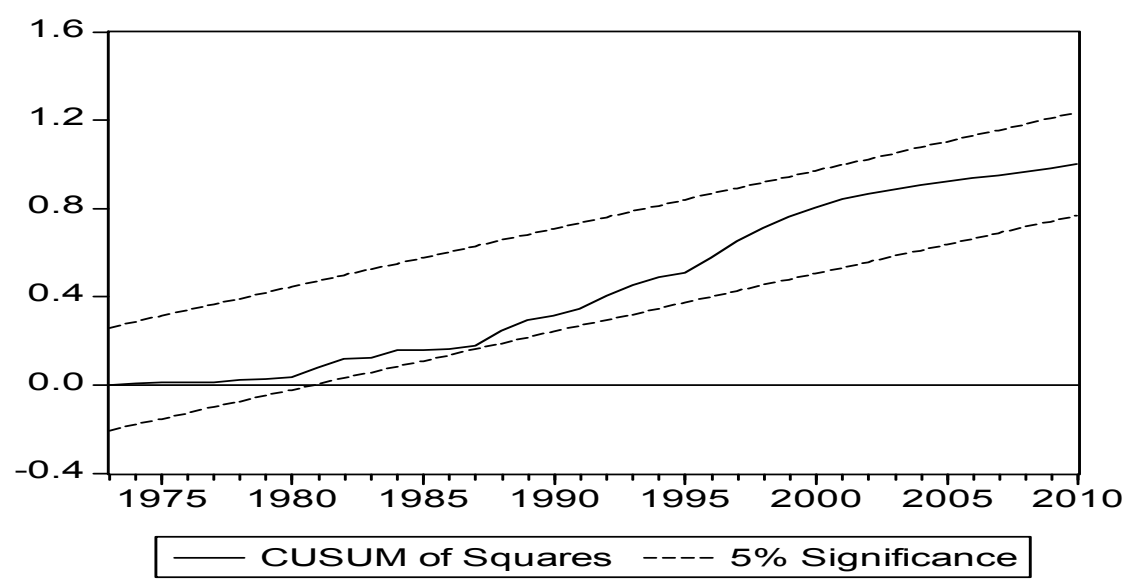

Figure 2. Plotting of CUSUMSQ statistics for stability test

\section{Conclusion and Policy Message}

The recent global financial crises which consequently forced the donors of foreign assistance to reduce their inflows (like oversea foreign assistance (ODA), foreign direct investment (FDI) and portfolio investments ) into developing countries brought about renewed interests in modelling the determinants of domestic private investment in Nigeria thus providing motivation for the study. In order to achieve the set objective, annual time 
series data over the period 1970 through 2010 was used. Further, advanced econometric technique of Auto-Regressive Distributed Lag (ARDL) bounds testing approach developed by Pesaran et al (2001) was employed. The interesting results from the findings showed that public investment, real GDP, real interest rate, exchange rate, credit to the private sector, terms of trade, external debts and reforms dummy are the key long run determinants of domestic private investment in Nigeria while public investment, real GDP and terms of trade are statistically significant in the short run.

The main policy messages emanating from these results are: first, since the positive impacts of public investment is arguably documented in most existing and recent literature, efforts should therefore be geared towards putting in place and spend on necessary public investments (infrastructures like constant electricity supply, good motorways, better health delivery system etc) so as to provide a conducive business environment which crowd-in domestic private investment as well as making other small and medium scale businesses to thrive. Second, since external debts constitute major drags on developmental efforts, most especially in the sub-Saharan region where such debts are not channeled towards the development of private sectors but rather being misappropriated, thus should be reduced to the barest minimum. Third, further reforms programme should be instituted in order to allow for more participation among the private sectors. Fourth, negative effects of external shocks engendered by foreign direct investment uncertainty and deficit terms of trade should be prevented. Lastly, since most of the key variables are significant in the long run than in the short run, it is however important for government to maintain policy consistencies in order not to stifling developmental efforts with her frequent policy somersaulting as being experienced in Nigeria, where new government jettisons the policy programmes of its predecessors.

\section{References}

Acosta, P., \& Loza, A. (2005). Short and Long Run Determinants of Private Investment in Argentina. Journal of Applied Economics, VIII(2), 389-406.

Adam, S. (2009, May). Can foreign direct investment (FDI) help to promote growth in Africa? African Journal of Business Management, 3(5), 178-183.

Akpalu, W. (2002). Modelling Private Investment in Ghana: An Empirical Time Series Econometrics Investigation (1970-1994). The Oguaa Journal of Social Sciences, 4.

Asante, Y. (2000). Determinants of Private Investment Behaviour. AERC Research Paper No. 100, Nairobi: AERC.

Aschauer, D. A. (1989, September). Does Public Capital Crowd out Private Capital. Journal of Monetary Economic., 24, 171-188. http://dx.doi.org/10.1016/0304-3932(89)90002-0

Berndt, E. (1990). The practice of econometrics: Classic and contemporary. MIT. Reading, Massachusetts.

Blejer, M., \& M. Khan. (1984). Government policy and private investment in developing countries. IMF Staff Papers, 31(2). http://dx.doi.org/10.2307/3866797

Brown, R. L., Durbin, J., \& Evans, J. M. (1975). Techniques for Testing the Constancy of Regression Relations Over Time. Journal of the Royal Statistical Society, 37, 149-192.

Busari, D. T, \& Omoke, P. C. (2008). Private Investment Behaviour and Trade Policy Practice in Nigeria. AERC Research Paper 177.

Calamitsis, E. A., Basu, A., \& Ghura, D. (1999). Adjustment and Growth in Sub-Saharan Africa. Working Paper, WP/99/51, Washington D.C.: International Monetary Fund.

Central Bank of Nigeria. (2004). Annual Report and Statement of Accounts for the year Ended $31^{\text {st }}$ December, 2004. CBC Abuja.

Chirinko, R. S. (1993). Business Fixed Investment Spending: Modelling Strategy, Empirical Results, and Policy Implications. Journal of Econometric Literature, 31,1875-1911.

Dailami, M., \& Walton, M. (1992). Private Investment, Government Policy and Foreign Capital: A Study of the Zimbabwean Experience.

Engle, R., \& Granger, C. (1987) Cointegration and error correction representation: estimation and testing. Econometrica, 55, 251-276. http://dx.doi.org/10.2307/1913236

Fowowe, B. (2011, September). Financial Sector Reforms and Private Investment in sub-Saharan African countries. Journal of Economic Development 79, 36(3).

Frimpong, J. M., \& Marbuah, G. (2010). The Determinants of Private Sector Investment in Ghana: An ARDL Approach. European Journal of Social Sciences, 15(2).

Greene, J., \& Villanueva, D. (1991). Private investment in developing countries: an empirical analysis. IMF Staff Papers, 38(1), 33-58. http://dx.doi.org/10.2307/3867034 
Gujarati, D. N. (1995). Basic Econometrics (3rd ed.). New York: McGraw-Hill.

Gyimah-Brempong, K., \& Traynor, T. L. (1999). Political Instability, Investment and Economic Growth in Sub-Saharan Africa. Journal of African Economies, 8(1), 52-86. http://dx.doi.org/10.1093/jae/8.1.52

Hoeffler, A. (2002). Openness, Investment and Growth. Journal of African Economies, 10(4), 470-497. http://dx.doi.org/10.1093/jae/10.4.470

Jalil, A., Ma, Y., \& Naveed, A. (2008). The finance-fluctuation nexus: Further evidence from Pakistan and China. International Research Journal of Finance and Economics.

Johansen, S. (1991). Estimation and hypothesis testing of cointegration vectors in Gaussian vector autoregressive models. Econometrica, 59, 1551-1580. http://dx.doi.org/10.2307/2938278

Johansen, S., \& Juselius, K. (1990). Maximum Likeliwood Estimation and Inference on Cointegration-With Application to the Demand for Money. Oxford Bulletin of Economics and Statistics, 52, 169-210. http://dx.doi.org/10.1111/j.1468-0084.1990.mp52002003.x

Jorgenson, D. W. (1971, December). Econometric studies of investment behaviour. Journal of Economic Literature.

Looney, R. E., \& Frederiken, P. C. (1997). Government Investment and Follow-on Private Sector Investment in Pakistan, 1972-1995. Journal of Economic Development, 22(1), 91-100.

Luintel, K. B., \& Mavrotas, G. (2005). Examining Private Investment Heterogeneity, Discussion Paper No 2005/11 for World Institute For Development Economic Research (WIDER).

Matsheka, T. C. (1998). Interest Rates, and the Saving-Investment Process in Botswana. African Review of Money Finance and Banking, 1(2), 5-23.

McKinnon, R. I. (1973). Money and Capital in Economic Development. Washington DC: The Brookings Institution.

Narayan, P. K. (2004). Reformulating Critical Values for the Bounds F-statistics Approach to Cointegration: An Application to the Tourism Demand Model for Fiji. Department of Economics, Discussion Papers, No. 02/04, University of Monash.

Ndikumana, L. (2000). Financial determinants of domestic investment in sub-Saharan Africa: Evidence from panel data. World Development, 28(2), 381-400. http://dx.doi.org/10.1016/S0305-750X(99)00129-1

Oshikoya, T. (1994). Macroeconomic Determinants of Domestic Private Investment in Africa: an Empirical Analysis. Economic Development and Cultural Change, 42(3), 573-595. http://dx.doi.org/10.1086/452103

Ouattara, B. (2005). Modelling the Long Run Determinants of Private Investment in Senegal. CREDIT Research Paper, Centre for Research in Economic Development and International Trade, University of Nottingham, No. 04.

Pesaran, M. H., \& Shin, Y. (1998). An Autoregressive Distributed-Lag Modeling Approach to Cointegration Analysis. In S. Strom (ed.), Econometrics and Economic Theory in the 20th Century: The Ragnar Frisch Centennial Symposium (pp. 371-413). Cambridge University Press, New York. http://dx.doi.org/10.1017/CCOL0521633230.011

Pesram, H. M., Shin, Y., \& Smith, R. (1999). Bounds Testing Approaches to the Analysis of Long- Run Relationship. Department of Applied Economics, University of Cambridge.

Pindyck, R. S. (1991). Irreversibility, uncertainty, and investment. Journal of Economic Literature, XXIX.

Ribeiro, M. B. (2001). An Econometric Analysis of Private-Sector Investment in Brazil. CEPAL Review, 74, 153-166.

Rodrik, D. (1991). Policy Uncertainty and Private Investment in Developing Countries. Journal of Development Economics, 36(2), 229-242. http://dx.doi.org/10.1016/0304-3878(91)90034-S

Seck, D., \& El Nil, Y. H. (1993). Financial Liberalization in Africa. World Development, 21(11), 1867-1881. http://dx.doi.org/10.1016/0305-750X(93)90088-Q

Serven, L., \& Solimano, A. (1992, January). Private investment and macroeconomic adjustment: A survey. The World Bank Research Observer, 7(1). http://dx.doi.org/10.1093/wbro/7.1.95

Shaw, E. S. (1973). Financial Deepening in Economic Development. New York: Oxford University Press.

Tobin, J. (1969). A General Equilibrium Approach to Monetary Theory. Journal of Money, Credit and Banking, l(1), 15-29. http://dx.doi.org/10.2307/1991374

Zebib, M., \& Muoghalu, M. (1998). Dynamic nature of private investment and its determinants in developing countries. Studies in Economics and Finance, 18(2), 100-110. 